Antoni Kukliński

\title{
DILEMMAS IN POLISH GEOGRAPHY
}

\section{INTRODUCTION}

The history of geography of Polonia Restituta is seen now in a different perspective.

The classical model of the descriptive analysis and cumulative approaches has been replaced by a more relevant paradigmatic model. In this model an important role is allocated to the explanation of the mechanisms of scientific revolutions which change the academic and social image of geography and generate new paradigms which determine, for some time, the performance of the given academic discipline.

In the history of geography of Reborn Poland three periods of the paradigmatic change are most interesting.

(1) The period of the twenties which formed paradigm I of geography in Reborn Poland.

(2) The period of the fifties which incorporated the process of annihilation of paradigm I and that of creation of paradigm II.

(3) The period of the eighties which incorporates the processes of accelerated decline of paradigm II and those of creation of paradigm III.

In this climate of paradigmatic change the short paper presented here has been written and published. It is a controversial paper probably not reflecting the point of view of the majority of Polish geographers. I think, however, that the challenge of 12 Dilemmas may be interesting not only for Polish geographers but also for my professional colleagues in wher countries.

\section{Dilemma 1. Monism or Pluralism}

Our attitude to the general idea of our discipline is ambivalent. We use the terms "geography" and "geographical sciences" as meaning the 
same. We should remember, however, that each of them has different methodological implications.

The term "geography" implies a monistic conception, that of one academic discipline combining natural, social and economic problems. For many geographers the monistic conception is almost a dogma; they believe there exists only one geography as a science with a wonderful power of integration and synthetization which is particularly manifested in case of regional geography.

The monistic conception of geography may be contrasted with the pluralistic conception of a group of geographical sciences which have few features in common, different fields of investigations and different interdisciplinary links.

Special emphasis should be laid on methodological differences between those geographical sciences which apply the methodology of natural sciences and those which use the methods of broadly understood social sciences.

Therefore, in my opinion, the pluralistic conception of "geographical sciences" gives a more adequate image of reality than the monistic conception of one geography.

In practice, however, even the advocates of the pluralistic conception prefer the term "geography" because of its simplicity and the possibility to turn the name of the science "geography" to a "geographer" as a profession.

Thus the economy of words is the reason for which I will use the term "geography" as synonymous for "geographical sciences".

The choice between monism and pluralism in geography has not only the institutional and methodological aspect. We may put a more essential question in searching philosophical basis for the development of geography. Representing the monistic conception, should the basis come from only one, strictly defined, philosophical trend or should there be a pluralism of philosophical inspirations? We may also find the third solution in which the academic comporation of geographers ignores the philosophical basis making an unspoken assumption that education and research do not require any deeper philosophical background. Such opinions create an atmosphere of a sui generis pragmatic technocracy which becomes an efficiently functioning substitute for philosophical basis in the development of geography.

Nevertheless it is only a substitute. For this reason we should start a serious discussion analysing the philosophical basis for the development of geographical sciences both in Poland and in many other countries in which geography has reached a high level of progress. 


\section{Dilemma 2. "Spatial" or "Environmental" Conception}

In a wide variety of definitions of geography as an academic discipline attention should be focused on two basic conceptions: (1) geography is a science of spatial differentiation; (2) geography is a science of an environment whatever the latter means.

It seems that in Polish socio-economic geography the first conception dominates, while in a broadly understood physical geography the other does.

I would like to put forward a hypothesis that a better knowledge and mutual integration of these two conceptions is an essential task to be undertaken by Polish geography of the eighties.

It is especially important to analyse the notion of "environment" in a comparative perspective of natural and social sciences. It is astonishing that geographers have retired into their discipline and in most cases have confined themselves to their own conception of geographical or natural envircnment making no comparisons with the related set of notions operated by other natural and social sciences.

That is why physical geography, ecology and socio-economic geography may not find a common ground with sociology and social eco$\log$.

I am convinced that in Poland of the eighties the geography of natural, social and economic environments will have special tasks in both fundamental and applied investigations.

That does not mean that the classical geography of spatial differentiation may be neglected.

In this respect a matter of great importance is the revival of Polish interests in the location theory without which geography of spatial differentiation would become a collection of banal descriptions.

One of the first elements in reconstructing Polish geography in the eighties is a serious study of the notions of "space and "environment". The studies should include not only the achievements of the world geography but also of other scierices which use these concepts.

\section{Dilemma 3. Qualitative or Quantitative Approach}

The future historians of science will explain why Polish geography of the sixties and seventies did not undergo the so-called quantitative revolution which much influenced the methodology of geographical investigations in other countries. That does not mean that the modernization of Polish geography in the eighties should include a specific version of accelerated and shortened quantitative revolution. 
In this case our backwardness is not only a negative phenomenon. We may thus avoid many mistakes made in other countries by the uncritical admirers of quantitative methods. We are aware that now neither in geography nor in other academic disciplines do the quantitative me-. thods guarantee an immediate success as it used to be several years ago. We may ask, however, what scientific, institutional and staff problems should be solved so that the quantitative methoids might play a proper role in the implementation of the substantial programme of the development of Polish geography in the eighties.

We shoulld also think of a new look at the qualitative methods. They may not be viewed as a conservative relic of the past. Let us consider the following problems:

(1) Qualitative presentations often produce scientific hypotheses which are later tested by quantitative methods.

(2) Qualitative methods often stimulate value judgements which maiy not be avoided in research, especially in social sciences. I agree with those who consider the "Wertfreiheit" conception to be artificial and false.

(3) Qualitative methods introduce not only strictly rational patterns of thinking and conclusions but also elements of intuition and emotion. The latter, when overabundant, are destructive for scientific research but the complete elimination of these factors makes the science inhuman.

(4) Qualitative presentations make us remember that the scientific language should serve not only the ideals of intellect but also the ideals of beauty. The success of the "qualitative" presentations in French geography consisted, among other things, in their beautiful language which often placed them on the border of scientific literature and belleslettres.

The modernization of Polish geography of the eighties should also care for the beauty of the language used in our geographical literature, both strictly scientific anid popular.

\section{Dilemma 4. Static or Dynamic Presentations}

It is impossible to overestimate the role of static presentations in the evaluation of research in the past and future. In the investigations of both spatial differentiations and environments of various kind geographers often reduce their range of view to static presentations which are often the first, but also the last, step towards the solution of the problem. 
Particularly in socio-economic geography the extension of the spatial comparative perspective is related to unisectional investigations, e.g. utilizing data of one census or, in further perspective, international comparisons.

Such static presentations often acquire a pseudodynamic character including for instance the comparison of spatial differentiation in several cross-sections-in-time. These investigations are often called comparative statics having little in common with real dynamic presentations which not only analyse static patterns but also, if not first of all, analyse processes which form and change spatial systems.

The problem of using the dynamic and processual presentations is a key-problem of geographical methodology and methodics. It is also one of the main issues of Polish geography of the eighties. Modernized geography in Poland must be a processual geography, able to identify, explain and forecast the action of the mechanisms governing the evo. lution of the investigated phenomena.

Dilemma 5. Objective or Subjective Approach

We have got accustomed to think that on objective approach is necessary for a scientific study. According to this convention, it is proper to find an objective presentation of an investigated phenomenon, i.e. a presentation which can be intersubjectively tested and thus independent of the investigating subject.

It is obvious that the role of an objective approach in the scientific progress is, and will be, decisive for cognitive processes. Nevertheless, the investigations on the perception of space and environment, developing on the border of geography and psychology, should not be excluded from the interests of Polish geographers. This is not only the objective image of the 'world that matters, but also its reflection in the consciousness of an individual and society. There are many examples proving that unreal images are often an essential and sometimes dangerous mechanism of social consciousness.

The geography of the eighties must find a common ground with psychology and launch an interdisciplinary programme of investigations on the perception of various kinds of space and environments by an individual and the society in our country.

Our backwardness in this respect is evident both in the theoretical reflection and empirical research. 
The main tendencies in the world and Polish geography made it a reistic science in the sense that it concentrated on the world of things, of touchable physical objects. In the sixties there appeared a new conception in the world geography which shifted the focus from things to information. The informative conception of geography found its fuliest expression in Sweden where new problems were introduced into investigations, concerning the flow of information, the formation of the so-called contact landscapes and the diffusion of innovations.

Swedish geographers may be said to have created a new paradigm of informative geagraphy which made Swedish geography leading in the world at the end of the sixties. In the middle of the seventies the new paradigm seemed to lose its driving force. Some Swedish geographers claimed a crisis and a necessity for searching new impluses for further evolution of that conception.

The informative conception of geography should nevertheless play an important role in the reconstruction and modernization of Polish geography in the eighties.

New ruless in the functioning of our society and economy, being shaped just now, demand studies which would adjust many elements of the informative conception of geography to Polish conditions. This does not mean, however, that the classical trend of reistic geography is going to lose its dominance in Polish geography in the future.

\section{Dilemma 7. Idiographic or Nomothetic Conceptions}

Idiographic conceptions are fundamental for the classical geography. This approach assumes that geography is a science of unique spatial contexts, in the same way as history is a science of unique temporal contexts. The main task of geography is to describe unique and unrepeated phenomena.

As an cipposition to the idiographic conception there appeared a nomothetic conception according to which the structure and the purposes of scientific study should be the same for geography and other academic disciplines, and should concentrate on investigating repeated phenomena. This conception allows us to try to discover the laws governing the mechanismis of the development of the investigated phenomena.

This point of view is very ambitious. There exist two simpler versions of the nomothetic geography. In the first one geography does not aim at the formulation of the laws of the development of the phenome- 
na but at the formulation of the laws of the spatial shape of these phenomena.

In the other version geography is not a "producer" of scientific laws but their consumer, and the laws are formulated by proper topical disciplines.

At the beginning of the sixties it seemed that the quantitative revolution would automatically change idiographic geography into the nomothetic science. That did not happen and the quantitative revolution did not become the driving force of a full methodological reconstruction of geography.

The problem of nomothetic geography remains open. Polish geography of the eighties should deal with the problem keeping in mind both the internal mechanisms of the development of that science and the role of Polish geographers in modelling the main trends in the world geography.

\section{Dilemma 8. Histarical or Prognostic Conceptions}

The fundamental duty of science is to explain reality. In most cases the explanation includes the historical perspective, going back to the origin of phenomena under investigation. In this sense the historical conception was, is and will be the main one in the development of geography. Therefore, it is necessary to revive the cooperation betweer geography and history, especially this trend in history which accepts elements of the nomothetic conception of science.

That does not diminish the role of proginostic conceptions in the development of geography. We should remember, however, that each prognosis is a mixture of knowledge, belief and imagination. Prognostic investigations will never be scientific in the full sense of the term. Prognostic investigations should not become an instrument of diverting our attention from the surrounding reality as it happened in Polish geography of the seventies.

In the eighties we must find a new equalibrium between the historical and prognostic conceptions in Polish geography. They both deserve a comprehensive analysis confronting our experience with that of other countries. In a few years prognostic studies will become fashionable again. The point is that we should be better prepared to start a speculative rather than an empirical science.

Dilemma 9. Fmpirical or Specuiative Conceptions

I would like to risk a statement that Polish geography has become a speculative rather than an empirical science. 
That situation is caused by the fact that many Polish geographers try to escape from laborius empirical investigations and look for more comfort in speculative studies. This is quite natural among geographers of older generation as many of them had aiready experienced their Sturm-und Drang-periode of empirical investigations. The trouble is with unwillingness of younger geographers who do not waint to go through their period of empirical Sturm-und Drang. The situation can be best illustrated by completely neglected empirical studies of industrial location.

For this reason in the eighties we must stimulate a new tide of enthusiasm for empirical studies in Polish geography. Without new achievements in studying the surrounding reality, and without decided intensification of empirical investigations we shall mot modernize that academic discipline.

\section{Dilemma 10. Substantial or Instrumental Conceptions}

Scholars may be divided into two groups. The first are substantialists who want to study the objective reality. For them the methods of investigations are a problem of secondary importance, subordinated to the substantial requirements and cagnitive purposes of a given research programme. The other group are instrumentalists, first of all interested in continuous improvements of the research methods and tools. For them the choice of a research problem is only an attempt to find a most effective and attractive exemplification of the application of a given instrument or method.

We may also find scientists who are substantialists and instrumentalists at the same time. There are many cases, however, in which the two styles of research are clearly separate. We may see that, for instance, the quantitative revolution in the world geography was made by instrumentalists.

In Polish geography the differences between substantialists and instrumentalists are less clear than e.g. in American geography. Nevertheless they do exist. The question is how the two styles should co -exist in Polish geography of the eighties. Let us hope that the number of Polish substantialists rationally using the wide range of modern research methods will increase. We may also present an opinion that there is a distinct need to consolidate the corporation of Polish instrumentalists. We need rational instrumentalists able to introduce the process of methodic and instrumental progress into the reality of the Polish geographical research programme of the eighties. 
Dilemma 11. Deterministic or Voluntaristic Conceptions

It seems that the role of determinism in geography should be analysed in a new light. It is not enough to state that determinism is a false and rejected system. Attention should also be paid to its positive role in the formation of geography as an academic discipline. Determinism was the first paradigm in the historical evolution of geography, the conception which produced a coherent and consistent convention explaining objective reality.

Determinism was a false conception. In my opinion, however, in the evolution of science false conceptions are less dangerous than a complete emptiness in the theoretical backgnound.

We should also consider the conception of modern determinism which would identify and analyse the bariers in natural phenomena limiting economic, social and political activities of the human being in various environmental systems. This neo-determinism would be a useful idea focusing our attention on extremely dangerous voluntaristic conceptions which are enfant terrible of the rapid growth of large-scale technical solutions broadly used in the second half of our century.

The analysis of a destructive influence of investiment voluntarism is a very important task of Polish geography of the eighties.

The task would at the same time integrate the efforts of the whole complex of geographical sciences in Poland.

\section{Dilemma 12. Theory or Practice}

I agree with the opinion that it is necessary to look for an optimal distance between theory and practice. The distance should be small enough so that the mechanisms of mutual penetration of inspiration could workt. But it must be large enough so that the scholars could feel independent in their judgements, critical opinions and free from the short-term pressure of the current moment. (By pressure of the current moment I mean not only the authorities but also another type of pressure created by the atmosphere of irrational social emotions).

From this point of view it is worth considering the situation in Polish geography of the seventies and the long ceremony of mutual admiration of theory and practice in the field of aménagement du territoire.

The problem of the relationship between theory and practice is essential for Polish geography of the eighties.

I do not believe in the ivory tower but I would not like us to work in the atmosphere of flattery and mutual admiration. 


\section{CONCLUSION}

Naturally, these 12 Dilemmas should not be taken too seriousiy. I understand very well that a competitive list of other dilemmas could and should be formulated. This paper should be only seen as an inducement in this direction.

However, this paper is but a brief outline of my ideas developed in different.contributions published in recent years. Eventually, the interested reader may kindly consider the suggestion to look at my contributions listed in the bibliography.

\section{BIBLIOGRAPHY}

Kukliński, A., (ed.), "Diagnoza stanu gospodarki przestrzennej Polski. Wstępne wyniki badan". (Diagnosis of the State of Space Economy in Poland. Preliminary Results) Biuletyn Komitetu Przestrzennego Zagospodarowania Kraju, Pclish Academy of Sciences, Vol. 123, Warszawa 1983.

$\mathrm{K}$ ukliński, A., (ed.), "Growth Poles and Growth Centres in Regional Planning". UNRISD-Mouton Regional Planning Series, Vol. 5, Paris The Hague 1972.

Kukliński, A., "Mechanizmy rozwoju geografii polskiej w latach 1945-1982. Artykuł dyskusyjny". (Polish Geography Mechanisms of Development in the Years 1945-1982) Przeglad Geograficzny, Vol. 55, No. 3, 1983.

Kukliński, A., (ed.), "Regional Studies in Poland: Experiences and Prospects", Studia Regionalia, Polish Academy of Sciences, Warszawa 1984.

Kuklinski, A., Research Activity of the Committee for Space Economy and Regional Planning in Poland, Cornell University Press, New York 1966, pp. $389-4.05$.

Kukliński, A., Space Economy and Regional Studies in Poland, United Nations Centre for Regicnal Development, Nagoya 1982.

Kukliński, A., "Studies in the History of Polish Geography: Observations and Reflections", GeoJurnal Vol. 7, No. 3, 1983.

Kukliński, A., "Polish Space in the Eighties", GeoJurnal, Vol. 7, No. 1, 1983, pp. $80-83$. 